\title{
4: 75067448-75069512
}

National Cancer Institute

\section{Source}

National Cancer Institute. 4: 75067448-75069512. NCI Thesaurus. Code C42041.

Physical location of CXCL6_Gene 